\title{
EFFECTS OF NANO AND CHEMICAL FERTILIZERS ON PHYSIOLOGICAL EFFICIENCY AND ESSENTIAL OIL YIELD OF BORAGO OFFICINALIS L.
}

\author{
MAHMOODI, P. ${ }^{1}$-YARNIA, M..$^{1 *}$ - RASHIDI, V. ${ }^{1}-$ AMIRNIA, R. ${ }^{2}-$ TARINEJHAD, A. ${ }^{3}$ \\ ${ }^{1}$ Department of Agronomy and Plant Breeding, Tabriz Branch, Islamic Azad University \\ Tabriz, Iran \\ ${ }^{2}$ Department of Agronomy and Plant Breeding, Urmia University, Urmia, Iran \\ ${ }^{3}$ Department of Agronomy and Plant Breeding, Azarbaijan Shahid Madani University \\ Tabriz, Iran \\ *Corresponding author \\ e-mail:m.yarnia@yahoo.com \\ (Received $10^{\text {th }}$ May 2018; accepted $11^{\text {th }}$ Jul 2018)
}

\begin{abstract}
This study was conducted to compare the effects of nano and chemical fertilizers on physiological efficiency and essential oil yield of Borago officinalis L. during 2013 and 2014 crop years. The different levels of fertilizers were used as main factors in 11 levels including iron-sulphate and nanoiron, zinc and nano-zinc, urea and nano-urea, potassium sulphate and nano-potassium, micro-complete and micro-complete nanosuper and control. The application methods of fertilizers were considered as secondary factor (soil application, foliar application and combined application). Physiological efficiency of nitrogen, phosphorous, potassium, zinc and iron, dry and fresh weight of aerial parts, number of secondary branches, chlorophyll content, 100 grains and essence yield were evaluated. Our findings showed that chemical fertilizers had no beneficial effects in comparison to nano fertilizers $(P>0.05)$. In addition, nano-urea and urea fertilizers increased essential oil yield because of increased wet and dry weight of aerial parts and number of secondary branches. In conclusion, nano-fertilizers can be used in order to improve the essence production and also as environmentally friendly fertilizers.
\end{abstract}

Keywords: environmentally friendly fertilizers, foliar application, nano-fertilizers, essential oil production, Borago officinalis $\mathrm{L}$.

\section{Introduction}

Medicinal plants are used in order to treat some incurable chronic disorders and by about $80 \%$ of the people of the world are dependent on medicinal plants for health and treatment (Ibrahim et al., 2013). There are increasing interest to use the medicinal plants because of side effects of synthetic drugs. Borage (Borago officinalis L.) is belonging to Boraginaceae family and it is traditionally used for therapeutic uses. Borage oil seed is rich source of essential fatty acids such as linoleic acid and $\gamma$-linolenic acid which can have beneficial effects on human health (Mhamdi et al., 2007). Some medicinal plants are known to have antioxidant and anti-inflammatory properties (Balasubramanian and Palaniappan, 2001) which are attributed to their essential oils. However, yield and content of essential oils are dependent on climate and geographical conditions, harvest time and application of fertilizers (Baranauskiene et al., 2003). Considering increased needs medicinal plants and effect of fertilizers on quantity and quality of essential oils, it is essential to use the best fertilizers in order to increase the efficiency of medicinal plants. Studies have reported that fertilizers increase the production of medicinal plants (Das et al., 2007; Sharma and Kumar, 2011). There are increasing interest to use the 
nanoparticles for industrial and pharmaceutical purposes (Siddiqui and Al-Whaib, 2014). Nanoparticles have high surface/volume ratio that increase biochemical activities and reactivity (Lee et al., 2008, 2010). It is still unknown interaction between biological systems and nanoparticles (Barrena et al., 2009). Nanotechnology is a strategy in order to increase the value of agriculture products and decreasing environmental problems (Elfeky et al., 2013). Kottegoda et al. (2011) have produced slow-released nanoparticles and nano powders. Studies have shown beneficial effects of nanoparticles on germination, growth and development in plants (Roghayyeh et al., 2010). Elfeky et al. (2013) reported positive effects of nano-iron on chlorophyll content, total carbohydrate, essential oil content and growth characteristics of Ocimum basilicum.

Nitrogen and potassium are nutrients influencing on production and quality in plants. Nitrogen modulates in chlorophyll synthesis and photosynthetic efficiency, but potassium regulates cell wall permeability and activity of different elements (Akamine et al., 2007). Potassium and nitrogen fertilizers increased turmeric production but had not significant effects on curcumin production (Akamine et al., 2007).

Regarding the use of chemical fertilizers in start of season, part of chemical form may be converted to other forms and/or deleted, resulting in increased economical harmful. In order to increase the efficiency of nutrients intake, fertilizers must provide essential nutrients during long times. Application methods can have significant effects on plants yield. Foliar application of some fertilizer may have more beneficial effects in comparison to soil application. It seems that the use of nano fertilizers may increase efficiency of essential oil production (Kennedy et al., 2004).

Physiological efficiency of elements can be defined as production of dry matter/unit absorbed nutrient element (Moll et al., 1982). The efficiency of element absorption is controlled by growth and morphology of root system in plants (Barbieri et al., 2008). Application of nitrogen fertilizers can have positive effects on grain yield and also develop procedures in order to improve the management of nitrogen (Flowers et al., 2004). Fertilizers efficiency can be applied in order to investigate the yield/per unit (Delbert and Ulter, 1989). Increased absorption efficiency and the use of nitrogen in grain yield are required in order to efficient processes for absorption, transformation, assimilation and nitrogen redistribution. The relative relation of processes and genotypic differences in nitrogen efficiency can be changed among genetic populations and different climates (Moll et al., 1982). Medicinal plants are required because of their high advantages. However, high production by nano fertilizer can be beneficial and environmentally friendly. To the best our knowledge, any study has not been conducted to compare of chemical and nano fertilizers on performance, essential oil yield and physiological efficiency of medicinal plants. Thus, the present study was conducted to evaluate the effects of chemical and nano fertilizers by methods of foliar and soil application on essential yield and physiological efficiency of elements in borage.

\section{Materials and methods}

This experiment was conducted during 2013 and 2014 crop years in Agriculture station of Islamic Azad University, Tabriz-Iran in the north-west of Iran (37 $24^{\prime} \mathrm{N}, 46^{\circ}$ $17^{\prime} \mathrm{E} ; 1360 \mathrm{~m}$ ). Soil $\mathrm{pH}$ was ranged from weak alkaline up to medium alkaline and the threat of salinity was not considered (Table 1). Seeds were prepared from Pakan Institute, Isfahan-Iran. This experiment was conducted in spilt plot trial based on randomized block completely design with 3 replications. The different levels of 
fertilizers were considered as follows; 1-iron-sulphate fertilizer, 2-nano-iron 10\% (2$3 \mathrm{~kg}$ or $4 \mathrm{~L} / \mathrm{ha}$ in irrigation form and/or foliar form in $2 \mathrm{ppm}$ concentration), 3- zinc sulphate, 4-nano-zinc $20 \%$ (1-2 $\mathrm{kg}$ or 2-4 L/ha in irrigation form and/or foliar form in $2 \mathrm{ppm}$ concentration, 5-urea, 6-nano-urea (2-3 kg or $4 \mathrm{~L} / \mathrm{ha}$ in irrigation form and/or foliar form in $2 \mathrm{ppm}$ concentration), 7- potassium sulphate, 8-nano-potassium 23\% (1$2 \mathrm{~kg}$ or 2-4 L/ha in irrigation form and/or foliar form in $2 \mathrm{ppm}$ concentration), 9- microcomplete, 10 - nano super micro-complete $(2-3 \mathrm{~kg}$ or $4 \mathrm{~L} / \mathrm{ha}$ in irrigation form and/or foliar form in $2 \mathrm{ppm}$ concentration) and 11-non-application of fertilizer (control). The method of fertilizer application was considered as secondary factor (soil application, foliar application and combination of soil and foliar application). Experimental treatments were as follows:

1) Soil+foliar application of zinc

2) Soil application of zinc

3) Foliar application of zinc

4) Soil+foliar application of nano-zinc

5) Soil application of nano-zinc

6) Foliar application of nano-zinc

7) Soil+foliar application of complete

8) Soil application of complete

9) Foliar application of complete

10) Soil+foliar application of complete nano

11) Soil application of complete nano

12) Foliar application of complete nano

13) Soil+foliar application of potassium

14) Foliar application of potassium

15) Soil application of potassium

16) Soil+foliar application of nano potassium

17) Soil application of nano potassium

18) Foliar application of nano potassium

19) Soil+foliar application of iron

20) Foliar application of iron

21) Foliar application of iron

22) Soil+foliar application of nano- iron

23) Soil application of nano- iron

24) Foliar application of nano- iron

25) Soil+foliar application of urea

26) Soil application of urea

27) Foliar application of urea

28) Soil+foliar application of nano-urea

29) Soil application of nano-urea

30) Foliar application of nano-urea

31) Control

Number of experimental plots was 99 plots with length of $4 \mathrm{~m}$, width 3 m with 4 rows planting and distance $75 \mathrm{~cm}$. The seeds were planted in distances of $15 \mathrm{~cm}$. Secondary plots were consecutively planted and a line was considered as non-planting. In order to prepare the land for planting, sowing and plotting were conducted. Fertilizer application was conducted on basis $150 \mathrm{~kg} / \mathrm{ha}$ for urea fertilizer and $200 \mathrm{~kg} / \mathrm{ha}$ for 
phosphorous and potassium fertilizers. The levels of iron, zinc, copper, boron and manganese were essential for growth requirements (Table 1).

Table 1. Some of physicochemical characteristics of field soil

\begin{tabular}{|c|c|c|c|c|c|c|c|c|c|}
\hline & \multirow{2}{*}{$\begin{array}{c}\text { Depth } \\
\text { (cm) }\end{array}$} & Iron & Copper & Zinc & Manganese & \multirow{2}{*}{\begin{tabular}{|l} 
Total \\
N\%
\end{tabular}} & Phosphorous & Potassium & Boron \\
\hline & & \multicolumn{4}{|c|}{ (ava) ppm } & & \multicolumn{3}{|c|}{ (ava) ppm } \\
\hline 2013 & $0-30$ & 0.43 & 0.38 & 0.8 & 1.15 & 0.11 & 39.72 & 352 & 2.12 \\
\hline 2014 & $0-30$ & 2.04 & 0.42 & 1.02 & 1.82 & 0.086 & 47.5 & 381 & 2.36 \\
\hline
\end{tabular}

The seeds were planted in 3 up to $5 \mathrm{~cm}$ depths of soil. Field irrigation was conducted by soil humidity condition and environmental conditions. After planting, foliar application was conducted. Foliar application of iron-sulphate, zinc sulphate (concentration of $5 \mathrm{ppm}$ ), potassium sulphate and urea fertilizer (5 ppm), complete fertilizer $(2 \mathrm{ppm})$ and nano fertilizers $(2 \mathrm{ppm})$ were conducted. Dry and fresh weight of aerial parts, 100 grain weight, chlorophyll index content, stem and leaf dry weight, leaf number, harvest index and plant height were measured. While growing plant, samples were collected from per plot (Mhamdi et al., 2007). While flowering plant, 5 plants were harvested for preparation of essential oil. Samples were then evaluated in order to determine the elements. Physiological efficiency of elements was calculated based on Equation 1.

$$
\mathrm{PE}\left(\mathrm{kg} \cdot \mathrm{kg}^{-1}\right)=(\mathrm{BYf}-\mathrm{BYu}) /(\mathrm{Pf}-\mathrm{Pu})
$$

where BYf is biological function (grain+straw) in fertilized plot $(\mathrm{kg}), \mathrm{BYu}$ is biological function (grain + straw) in non-fertilized plot $(\mathrm{kg})$, Pf is fertilizer absorption (grain+ straw) in fertilized plot $(\mathrm{kg})$ and $\mathrm{Pu}$ is fertilizer absorption (grain+ straw) in nonfertilized plot $(\mathrm{kg})$.

Crop efficiency can be resulted from economical production/absorption unit of nutrients based on Equation 2.

$$
\operatorname{APE}\left(\mathrm{kg} \cdot \mathrm{kg}^{-1}\right)=(\mathrm{Gf}-\mathrm{Gu}) /(\mathrm{Pf}-\mathrm{Pu})
$$

where Gf is grain yield/fertilized plot $(\mathrm{kg}), \mathrm{Gu}$ is grain yield/non-fertilized plot, $\mathrm{Pf}$ is fertilizer absorption (grain+straw)/fertilized plot and $\mathrm{Pu}$ is fertilizer absorption (grain+straw)/non-fertilized plot.

The collected data was analyzed and the means were compared by using Duncan test at levels of 5\%. The SAS software was used to analyze the data and figures were illustrated by Excel software.

\section{Results and discussion}

The data for analysis of variances of the evaluated traits are presented in Table 2. 
Table 2. Analysis of variance of traits evaluated in borage

\begin{tabular}{|c|c|c|c|c|c|c|c|c|}
\hline Sources of variation & df & $\begin{array}{c}\text { Fresh } \\
\text { weight } \\
\text { of aerial } \\
\text { parts }\end{array}$ & \begin{tabular}{|c|} 
Dry \\
weight \\
of \\
aerial \\
parts
\end{tabular} & $\begin{array}{c}\text { Number } \\
\text { of } \\
\text { secondary } \\
\text { branches }\end{array}$ & $\begin{array}{c}\text { Chlorophyll } \\
\text { index } \\
\text { content }\end{array}$ & $\begin{array}{l}\text { Leaf } \\
\text { area }\end{array}$ & $\begin{array}{c}100 \\
\text { grain }\end{array}$ & $\begin{array}{c}\text { Essential } \\
\text { oil }(\%)\end{array}$ \\
\hline Year & 1 & $157.57^{\mathrm{ns}}$ & $18.44^{\mathrm{ns}}$ & $96.57^{* *}$ & $2601.11^{\mathrm{ns}}$ & $9365641.37^{* *}$ & $0.074^{\mathrm{ns}}$ & $0.01^{\mathrm{ns}}$ \\
\hline Replication (year) & 4 & $623.57^{* *}$ & $9.03^{* *}$ & $2.04^{*}$ & $404.50^{* *}$ & $117984.60^{\mathrm{ns}}$ & $0.028^{* *}$ & $1.09^{* * *}$ \\
\hline Fertilizer type & 10 & $257.77^{* *}$ & $3.08 *$ & $9.25^{*}$ & $755.13^{\mathrm{ns}}$ & $1425064.83^{\text {ns }}$ & $0.019^{* *}$ & $7.0005^{* *}$ \\
\hline Year $\times$ fertilizer type & 10 & $72.46^{* *}$ & $0.95^{* *}$ & $2.96^{*}$ & $507.50^{* *}$ & $715342.16^{* *}$ & $0.001^{\mathrm{ns}}$ & $1.03^{*}$ \\
\hline $\begin{array}{l}\text { Replication } \times \text { fertilizer } \\
\text { type (year) }\end{array}$ & 40 & $28.37^{* *}$ & $0.68^{* *}$ & $1.49^{* *}$ & $61.31^{\mathrm{ns}}$ & $40311.93^{\mathrm{ns}}$ & $0.012^{\mathrm{ns}}$ & $0.49^{* *}$ \\
\hline Application type & 2 & $16.05^{\mathrm{ns}}$ & $0.47^{\mathrm{ns}}$ & $0.33^{\mathrm{ns}}$ & $88.11^{*}$ & $1095386.67^{\mathrm{ns}}$ & $0.006^{*}$ & $0.01^{\mathrm{ns}}$ \\
\hline $\begin{array}{c}\text { Fertilizer } \\
\text { type } \times \text { application type }\end{array}$ & 20 & $37.61^{* *}$ & $0.48^{\mathrm{ns}}$ & $2.50^{\mathrm{ns}}$ & $253.91^{* *}$ & $648198.75^{*}$ & $0.017^{* *}$ & $0.362^{\mathrm{ns}}$ \\
\hline Year $\times$ application type & 2 & $11.49^{\mathrm{ns}}$ & $0.10^{\mathrm{ns}}$ & $1.87^{\mathrm{ns}}$ & $4.98^{\mathrm{ns}}$ & $186842.71^{\mathrm{ns}}$ & $0.00021^{\mathrm{ns}}$ & $0.184^{\mathrm{ns}}$ \\
\hline $\begin{array}{l}\text { Year } \times \text { application } \\
\text { type } \times \text { fertilizer type }\end{array}$ & 20 & $11.42^{\mathrm{ns}}$ & $0.24^{*}$ & $1.74^{* *}$ & $28.27^{\mathrm{ns}}$ & $309860.44^{* *}$ & $0.0030^{\mathrm{ns}}$ & $0.32^{* *}$ \\
\hline Error & 88 & 6.42 & 0.141 & 0.65 & 51.99 & 6646.61 & 0.008 & 0.147 \\
\hline $\mathrm{CV}(\%)$ & - & 7.55 & 9.87 & 8.17 & 22.06 & 19.96 & 5.17 & 20.21 \\
\hline
\end{tabular}

ns: non- significant, $* *$ and $*$ significant at the $1 \%, 5 \%$ probability levels, respectively

\section{Number of secondary branches}

The variance analysis of data showed significant interaction between fertilizer type and application method (Fig. 1) (P < 0.01). The most number of secondary branches (13.29 \& 13.14) were observed in soil application + foliar application of nano-urea and soil application of nano micro-complete. A combination of soil and foliar application of nano-urea fertilizer increased $1.14 \%$ number of secondary branches in comparison to nano micro-complete; indicating that similar efficiency the both fertilizers. The lowest number of secondary branches was firstly observed in foliar application of iron (8.85), followed foliar + soil application of urea (8.95), foliar application of potassium (9.00) and foliar application of nano-zinc (9.04). However, application of complete nano, nano-potassium and nano-urea increased secondary branches compared with control group $(P<0.05)$. The increased branch numbers in nano-urea treatment may be attributed to slow-degraded of urea and its role in growth and development. On the other words, increased branches in nano-urea treatment can be explained by increased penetration rate of required nutrients for growth reactions. Increased nitrogen rate could increase secondary branches in Matricaria chamimilla L. (Dastborhan et al., 2010). Increased nano treatment can be explained by increasing permeability nano fertilizers 
into leaf tissue and increasing nutrient penetration which increases growth parameters. Controlling elements is one of nanotechnology advantages (Hassani et al., 2015). The lowest number of branches was found in iron treatment. Iron is essential for plants growth but its application may have adverse effects on growth and development in plants, because it induces oxidative stress in plants (Briat et al., 2010). In addition, phyroferitine degrades and releases iron, produces hydroxyle iones (Zhang et al., 2013) and finally decreases growth.

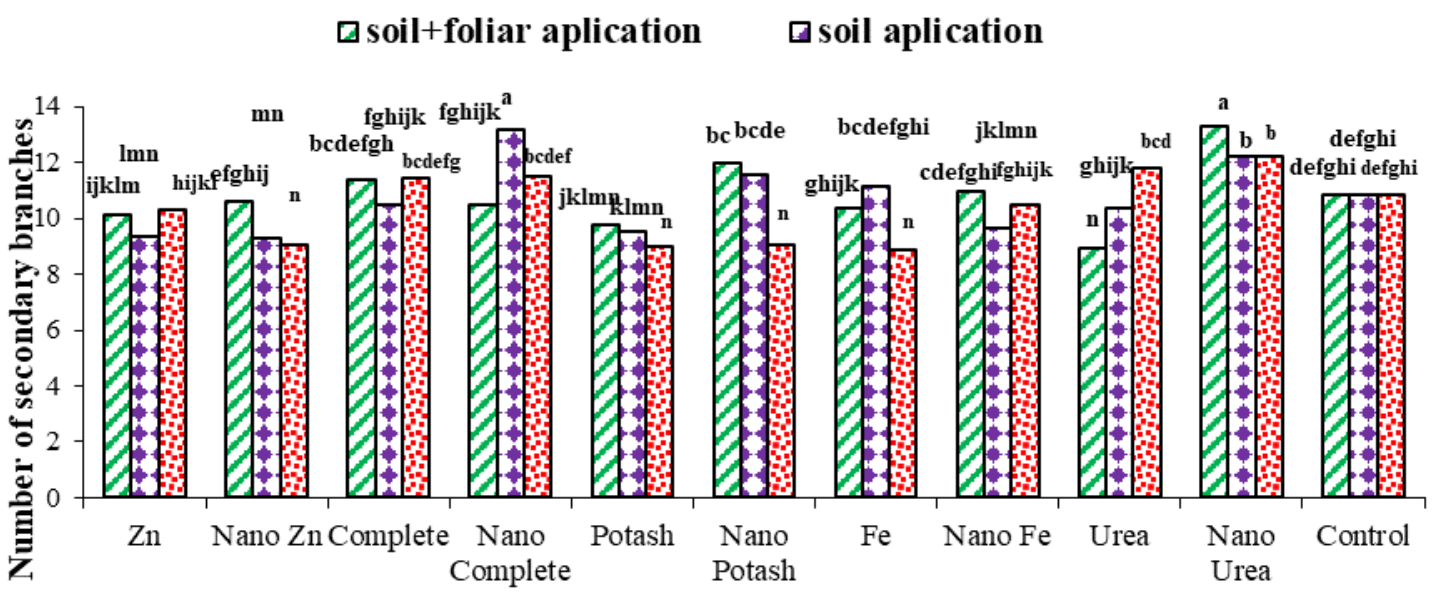

The different levels of fertilizer

Figure 1. Effects of fertilizer and application type on number (n) of secondary branches in borage

\section{Wet and dry weight of flowering aerial parts}

The highest fresh weight of flowering aerial parts was observed in foliar and soil application treatment of urea. Our findings showed that foliar application of urea increased weight by $51.1 \%$ in comparison to control group (Fig. 2). Urea, nano-urea, nano-iron, iron and nano-potassium had higher weight in comparison to control group.

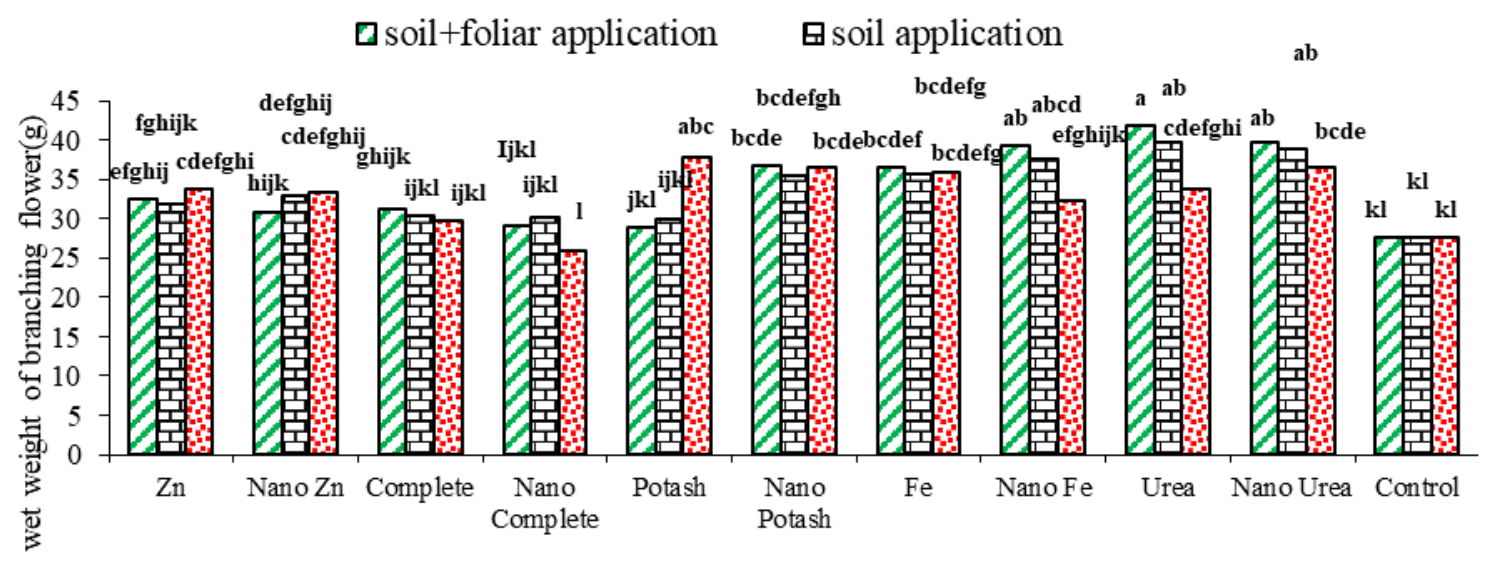

The different levels of fertilizer

Figure 2. Effects of fertilizers type and utilization methods on fresh weight $(\mathrm{g})$ of the branching flower 
The mean comparison of fertilizer types showed that the highest dry weight of aerial parts was observed in urea treatment $(4.20 \mathrm{~g})$. Application of urea could cause significant differences in comparison to nano-zinc, micro-complete and complete nano. The lowest dry weight of aerial parts was observed in control group (2.87 g) and application of urea increased dry weight of aerial parts in comparison to control group by $46 \%$ (Fig. 3).

The comparison of chemical and nano fertilizers did not show significant differences between chemical and nano fertilizers for dry weight of aerial parts, but nano fertilizers showed more efficiency compared to chemical fertilizers $(P>0.05)$. Except zinc fertilizers, application of nano-zinc in combined method, complete, complete nano and potassium in combined application and soil application could show better efficiency in comparison to control group. Nitrogen is an essential nutrient in order to increase the growth parameters in medicinal plants (Akamine et al., 2007). Deficient nitrogenous fertilizers decreased chlorophyll contents in leaves and immature death in plants. Chlorophyll level was appropriate in urea and nano-urea groups and it was no observed difference between urea and nano-urea for chlorophyll in combined application method. Nanofertilizers may prevent to loss nitrogen and longtime use of microorganisms. Slowreleased of nitrogen in nano-urea fertilizers may decrease toxic effects in high application (Gendy et al., 2013). Nitrogen not only participates in structure of purines, pyrimidines and enzymes but also participates in chlorophyll and cytochrome structure (Gendy et al., 2013). However, results showed that urea and nano-urea fertilizers had most efficiency. This result shows that nanoparticles are absorbed by root apex, cell wall and vascular system in plants (Lv et al., 2015).

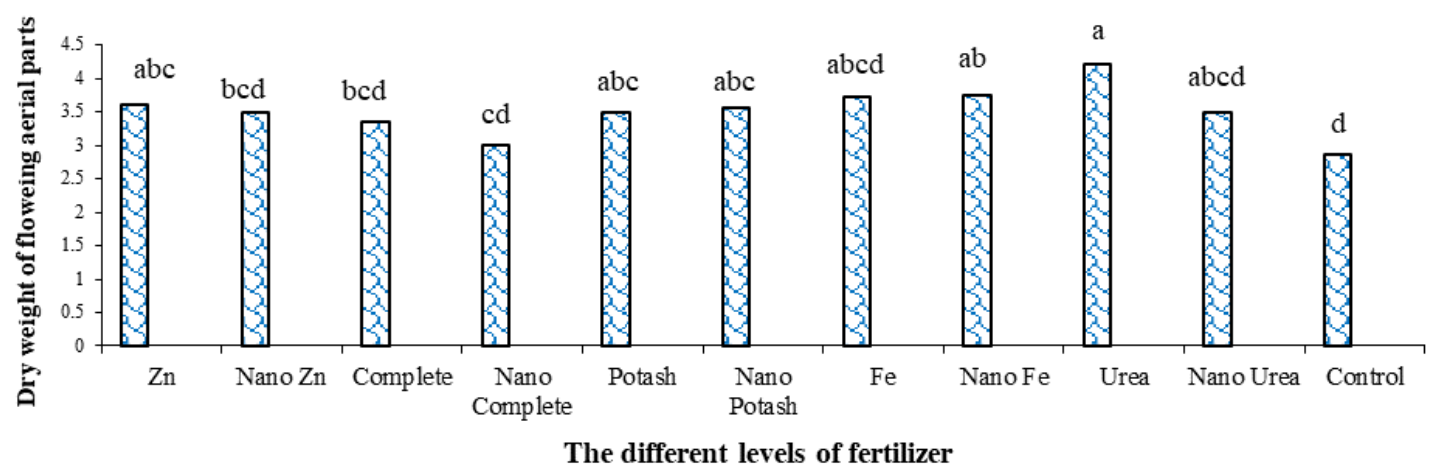

Figure 3. Effects of fertilizers type and application methods on dry weight $(g)$ of aerial parts in borage

\section{Leaf area}

Interaction between different levels and application methods of fertilizers on leaf area was significant (Table 2). The highest leaf area $\left(1706 \mathrm{~cm}^{2}\right)$ was observed in soil + foliar application of nano-urea and foliar application of urea (Fig. 4). Application of zinc fertilizers in soil application, foliar + soil application of zinc, combined application of complete, soil application of complete fertilizers respectively increased leaf area $64 \%, 3 \%, 37 \%$ and 50\% in comparison to control group (Fig. 4). It seems that nano-urea fertilizer is slowly released in soil and increases leaf area and photosynthetic activity in plants (Kottegoda et al., 2011). Increased efficiency of nitrogen is one of critical factors in order to decrease environment pollutants. Increased leaf area not only 
depends on genetically factors but also leaf nitrogen. Nitrogen supplement can have significant effects on leaf activity. On the other hand, nitrogen modulates in growth and development in plants. Increased number and leaf area increased the chlorophyll structure, involved enzymes and increasing essential oil yield (Briat et al., 2015).

\section{Chlrophyll contents index}

Analysis of variance showed significant interaction between the different levels of fertilizer and application method on chlorophyll index (Table 1). The mean comparison showed that highest chlorophyll index was observed in soil application of complete $(\mathrm{CCI}=50.91)$ and nanozinc $(\mathrm{CCI}=48.35)$ (Fig. 4). The lowest chlorophyll index $(\mathrm{CCI}=18.4)$ was observed in control treatment (Fig. 6). Zinc, nanozinc, complete, nano complete, potassium, nano potassium, urea and nano-urea fertilizers had chlorophyll indexes in comparison to control group. Application of urea and biological fertilizers increased chlorophyll contents in guar (Gendy et al., 2013). They have also reported increased chlorophyll contents can be attributed to levels of nitrogen and its role in chlorophyll synthesis. Nitrogen participates in chlorophyll synthesis and photosynthetic efficiency. Potassium regulates permeability of cell wall and activity of different cells (Akamine et al., 2007). Amujoyegbe et al. (2007) reported that nitrogen and magnesium can be released by chemical fertilizers and participate in porphyrine ring of chlorophyll molecule.

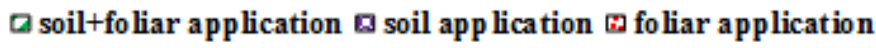

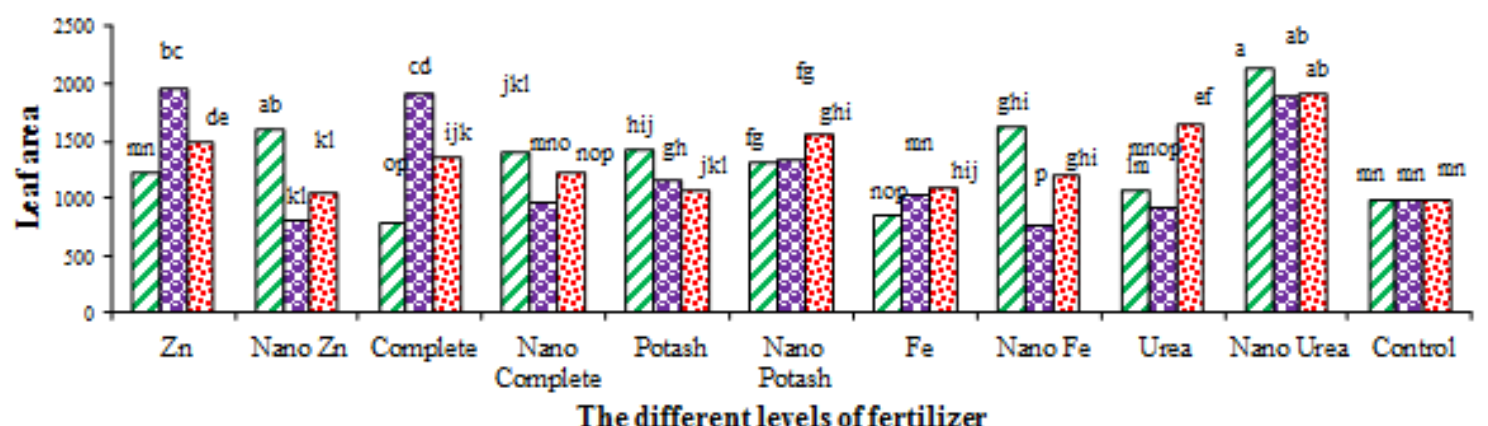

Figure 4. Effects of fertilizers type and application methods on leaf area $\left(\mathrm{mm}^{2}\right)$ of borage

\section{Essence percentage}

Mean comparison of essence showed that nano-urea fertilizer and control treatments had most and lowest essence contents, respectively. Nano-urea treatment could increase essence percentage in comparison to zinc and control treatments $200 \%$ and $191.4 \%$, respectively. There are conflicts reports in relation with nitrogenous fertilizers. Biesiada and Kucharska (2008) reported increased use of nitrogenous fertilizers increased the essence and phenolic contents. Lucy et al. (2004) have reported a reverse relation between essence percentage and nitrogen content. Gendy et al. (2013) showed that use of nitrogenous fertilizers and biological fertilizers increased essence percentage in guar. Fhatuwani (2008) showed increased essence yield and phenol production by nitrogenous fertilizers. 


\section{Essence yield}

The mean comparison showed significant effect of different fertilizers on essential oil yield during 2013 years $(\mathrm{P}<0.05$, Fig. 5). Nano-urea fertilizer $(10.96 \mathrm{mg} / \mathrm{ha})$ and control treatment showed highest and lowest essential oil yield, respectively (Fig. 6). Results showed that application of nano-urea fertilizers did not have significant difference with nano potassium and micro-complete $(\mathrm{P}>0.05)$. The mean comparison of treatments showed that application of nano-zinc fertilizer increased essential oil yield in comparison to chemical fertilizers, but the difference was not significant. Application of nano-zinc fertilizer increased essential oil yield (105.4\%) in comparison to control group (Fig. 5).

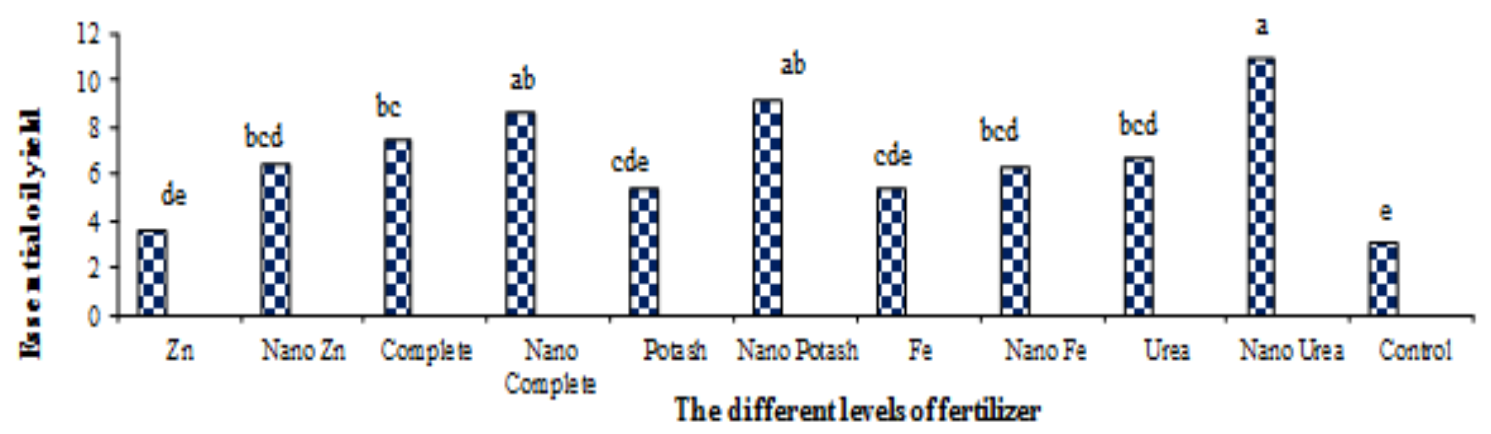

Figure 5. Effects of different fertilizers on essential oil yield (\%) during 2013 year

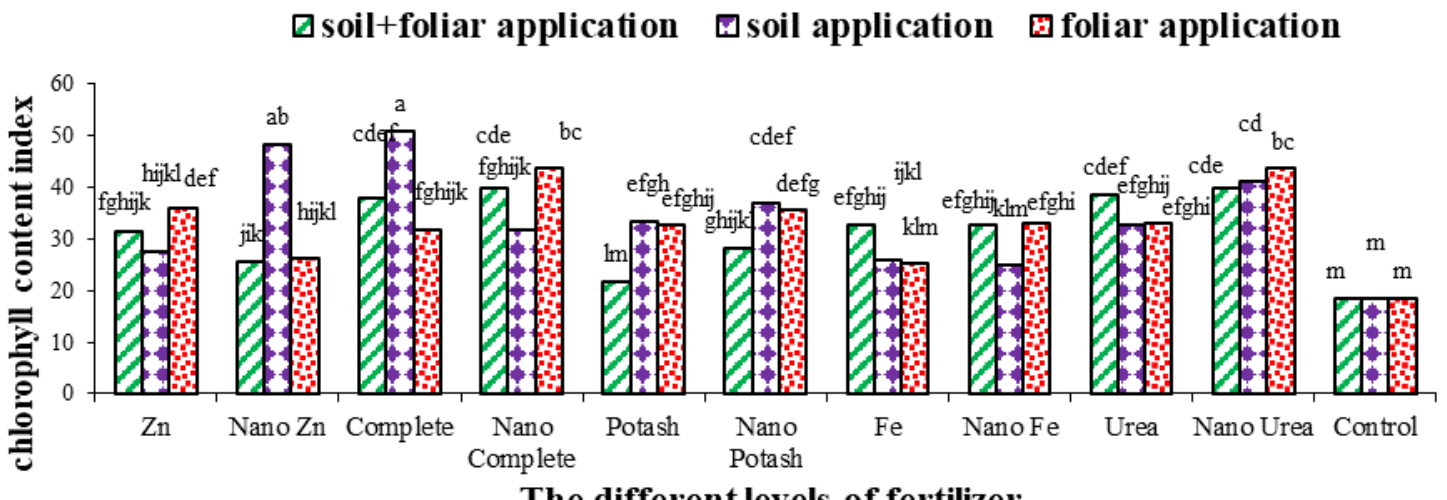

The different levels of fertilizer

Figure 6. Effects of fertilizers type and application methods on chlorophyll content index in borago

Micro-complete and potassium fertilizers increased essential oil yield $15.4 \%$ and $71.5 \%$ in comparison to micro-complete and potassium fertilizers, respectively. It was no observed significant difference between nano potassium fertilizer in comparison to nano micro-complete (Fig. 5). Results showed that nano fertilizer had most essential oil yield but it was no observed significant difference with nano potassium and complete nano. With regards to the different levels of chemical fertilizers, micro-complete treatment $(7.5 \mathrm{mg} / \mathrm{ha})$ showed most essential yield in comparison to control group (Fig. 5). Results also showed that micro-complete treatment increased essential oil yield rather than potassium (39.6), iron (37.3) and urea (11.9) fertilizers (Fig. 5). Nanozinc, 
complete, nano-complete, nano-potassium, nano-iron, urea and nano-urea increased essential oil yield in comparison to control group. Nano-potassium rather than potassium, nano-urea rather than urea showed significant increase in essential oil yield.

Our findings showed significant interaction between fertilizer type and application method on essential oil yield during 2014 years (Table 3). Results showed that the highest essential oil yield was observed in combined application of nano iron $(12.17 \mathrm{mg} / \mathrm{ha})$, followed foliar application of nano-urea $(12.07 \mathrm{mg} / \mathrm{ha})$, soil application of nano-urea (11.92 mg/ha), combined application of nano-urea (11.83 mg/ha) (Fig. 7). Results showed that foliar + soil application of nano iron, foliar application of nanourea, soil application and combined application of nano-urea and soil application of nano iron had not significant effects on essential oil yield (Fig. 7). Results showed that soil application of nano-zinc increased essential oil yield by $25.5 \%$ and $25.1 \%$ in comparison to foliar+soil application of nano-zinc and soil application of nano-zinc (Fig. 6). Soil application of nano potassium increased essential oil yield in comparison to foliar application of nano potassium, combined application of potassium and foliar application of nano potassium. Mean comparison of iron fertilizer showed that most essential oil yield was observed in combined application and soil application of nano iron (Fig. 6). Nano-urea fertilizer showed significant difference with urea fertilizer (Fig. 6).

Table 3. The mean comparison of year, fertilizer type and fertilizer application during two year

\begin{tabular}{|c|c|c|c|c|}
\hline & \multicolumn{2}{|c|}{ Dry weight of aerial parts } & \multicolumn{2}{|c|}{ Essential oil } \\
\hline & 2013 & 2014 & 2013 & 2014 \\
\hline Soil+foliar application of zinc & $3.62^{\mathrm{abcd}}$ & $3.66^{\text {fghij }}$ & $1.21^{\mathrm{fgh}}$ & $1.27^{\mathrm{hijk}}$ \\
\hline Soil application of zinc & $3.49^{\mathrm{abcd}}$ & $3.76 \mathrm{e}^{\mathrm{fghi}}$ & $1.01^{\mathrm{fgh}}$ & $1.69^{\text {fghij }}$ \\
\hline Foliar application of zinc & $3.69^{\mathrm{abcd}}$ & $4.05^{\operatorname{cdefg}}$ & $0.75^{\mathrm{h}}$ & $1.23^{\text {hijk }}$ \\
\hline $\begin{array}{l}\text { Soil+foliar application of nano- } \\
\text { zinc }\end{array}$ & $3.49^{\mathrm{abcd}}$ & $4.17^{\mathrm{bcdef}}$ & $1.66^{\text {cdefgh }}$ & $2.00^{\text {bcdefghi }}$ \\
\hline Soil application of nano-zinc & $3.34^{\mathrm{bcd}}$ & $4.13^{\text {bcdefgh }}$ & $1.79^{\text {cde }}$ & $2.67^{\mathrm{abcde}}$ \\
\hline Foliar application of nano-zinc & $3.62^{\mathrm{abcd}}$ & $4.48^{\text {bcde }}$ & $2.00^{\mathrm{bcdefg}}$ & $2.48^{\text {abcdef }}$ \\
\hline $\begin{array}{l}\text { Soil+foliar application of } \\
\text { complete }\end{array}$ & $3.60^{\mathrm{abcd}}$ & $3.73^{\text {efghi }}$ & $2.11^{\text {bcdef }}$ & $2.32^{\text {abcdefg }}$ \\
\hline Soil application of complete & $3.30^{\mathrm{bcd}}$ & $3.30^{\mathrm{hij}}$ & $2.08^{\text {bcdefg }}$ & $2.36^{\mathrm{abcdef}}$ \\
\hline Foliar application of complete & $3.18^{\mathrm{bcd}}$ & $3.63^{\text {fghij }}$ & $2.57^{\text {abcde }}$ & $2.38^{\text {abcdef }}$ \\
\hline $\begin{array}{c}\text { Soil+foliar application of } \\
\text { complete nano }\end{array}$ & $3.13^{\mathrm{bcd}}$ & $5.42^{\mathrm{a}}$ & $2.92^{\mathrm{ab}}$ & $2.57^{\text {abcdef }}$ \\
\hline $\begin{array}{l}\text { Soil application of complete } \\
\text { nano }\end{array}$ & $3.08^{\mathrm{bcd}}$ & $3.74^{\text {efghi }}$ & $2.89^{\mathrm{ab}}$ & $2.60^{\text {abcdef }}$ \\
\hline $\begin{array}{l}\text { Foliar application of complete } \\
\text { nano }\end{array}$ & $2.82^{\mathrm{d}}$ & $3.45^{\text {ghij }}$ & $2.91^{\mathrm{ab}}$ & $2.99^{\mathrm{a}}$ \\
\hline
\end{tabular}




\begin{tabular}{|c|c|c|c|c|}
\hline $\begin{array}{l}\text { Soil+foliar application of } \\
\text { potassium }\end{array}$ & $3.34^{\mathrm{bcd}}$ & $4.01^{\text {cdefgh }}$ & $1.57^{\mathrm{fgh}}$ & $1.26^{\mathrm{hijk}}$ \\
\hline Soil application of potassium & $3.35^{\mathrm{bcd}}$ & $3.61^{\text {fghij }}$ & $1.42^{\text {fgh }}$ & $0.95^{\mathrm{k}}$ \\
\hline Foliar application of potassium & $3.81 \mathrm{bcd}$ & $3.78^{\text {defghi }}$ & $1.61^{\mathrm{efgh}}$ & $1.17^{\mathrm{ijk}}$ \\
\hline $\begin{array}{l}\text { Soil+foliar application of nano } \\
\text { potassium }\end{array}$ & $3.50^{\mathrm{abcd}}$ & $4.45^{\text {bcde }}$ & $2.59^{\text {abcde }}$ & $2.87^{\mathrm{ab}}$ \\
\hline $\begin{array}{l}\text { Soil application of nano } \\
\text { potassium }\end{array}$ & $3.66^{\mathrm{abcd}}$ & $4.56^{\mathrm{bc}}$ & $2.68^{\mathrm{abc}}$ & $1.74^{\text {efghij }}$ \\
\hline $\begin{array}{l}\text { Foliar application of nano } \\
\text { potassium }\end{array}$ & $3.54^{\mathrm{abcd}}$ & $4.20^{\text {bcdef }}$ & $2.62^{\mathrm{abcde}}$ & $1.29^{\mathrm{hijk}}$ \\
\hline Soil+foliar application of iron & $3.60^{\mathrm{abcd}}$ & $3.14^{\mathrm{ij}}$ & $1.63^{\mathrm{defgh}}$ & $1.04^{\mathrm{ijk}}$ \\
\hline Soil application of iron & $3.93^{\mathrm{ab}}$ & $4.43^{\text {bcde }}$ & $1.49^{\mathrm{fgh}}$ & $0.62^{\mathrm{k}}$ \\
\hline Foliar application of iron & $3.61^{\mathrm{abcd}}$ & $4.26^{\text {bcde }}$ & $1.29^{\mathrm{fgh}}$ & $1.32^{\text {hijk }}$ \\
\hline $\begin{array}{l}\text { Soil+foliar application of nano- } \\
\text { iron }\end{array}$ & $3.92^{\mathrm{ab}}$ & $4.83^{\mathrm{ab}}$ & $1.40^{\mathrm{fgh}}$ & $3.08^{\mathrm{a}}$ \\
\hline Soil application of nano- iron & $3.91^{\mathrm{ab}}$ & $4.51^{\mathrm{bcd}}$ & $1.88^{\text {cdefgh }}$ & $2.77^{\mathrm{abcd}}$ \\
\hline Foliar application of nano- iron & $3.45^{\text {abcd }}$ & $4.14^{\text {bcdefg }}$ & $1.71^{\text {cdefgh }}$ & $1.40^{\text {ghijk }}$ \\
\hline Soil+foliar application of urea & $4.29^{\mathrm{a}}$ & $4.87^{\mathrm{ab}}$ & $1.61^{\mathrm{efgh}}$ & $1.71^{\text {efghijk }}$ \\
\hline Soil application of urea & $4.37^{\mathrm{a}}$ & $4.50^{\mathrm{bcd}}$ & $1.52^{\mathrm{fgh}}$ & $1.83^{\text {defghij }}$ \\
\hline Foliar application of urea & $3.95^{\mathrm{ab}}$ & $4.7^{6 a b c}$ & $1.66^{\text {cdefgh }}$ & $1.87^{\text {cdefghij }}$ \\
\hline $\begin{array}{c}\text { Soil+foliar application of nano- } \\
\text { urea }\end{array}$ & $3.70^{\mathrm{abcd}}$ & $5.41^{\mathrm{a}}$ & $2.65^{\mathrm{abcd}}$ & $2.18^{\text {abcdefggh }}$ \\
\hline Soil application of nano-urea & $3.61^{\mathrm{abcd}}$ & $5.29^{\mathrm{a}}$ & $3.38^{\mathrm{a}}$ & 2.44abcdef \\
\hline Foliar application of nano-urea & $3.22^{\mathrm{bcd}}$ & $4.51^{\mathrm{bcd}}$ & $3.16^{\mathrm{a}}$ & $2.82^{\mathrm{abc}}$ \\
\hline Control & $2.87^{\mathrm{cd}}$ & $3.03^{\mathrm{j}}$ & $1.05^{\mathrm{gh}}$ & $1.17^{\mathrm{ijk}}$ \\
\hline
\end{tabular}

Means by the uncommon letter are significantly different according to Duncan tests $(\mathrm{p}<0.05)$.

Biesiada and Kucharska (2008) have reported increased nitrogen could enhance essential oil yield and phenolic contents. Studies have reported reverse relation between essential oil yield and nitrogen content (Lucy et al., 2004). Najafi Vafa et al. (2015) stated that the use of nano-zinc increased essential oil yield in savory. El Gendy et al. (2013) showed that the use of nitrogenous fertilizers and biological fertilizers increased essential oil percentage in guar. Fhatuwani (2008) related essential oil yield with increased phenolic compounds by nitrogenous fertilizers. Regarding increased leaf area, 
it can be stated that photosynthesis and photosynthetic productions have direct relation with essential oil production. With regards to correlation between photosynthesis and essential oil production, it can be stated that carbon dioxide and glucose are essential oil for essential oil production. Considering the states mentioned, it seems that increased of leaf area, number of pores and glucose are essential for energy supply. Potassium and phosphorous improve effect of nitrogen on photosynthesis by oligodynamical role or participation in energy transformation, activating kinases and participating in osmotic absorption. Comparing nano-urea, urea and control show that as chlorophyll index increases, photosynthesis increases which can have major effect on essential oil production. Nitrogen modulates in cell division and development of new cells and also participates in chlorophyll structure and involves in carbon metabolism and essential oil yield (Briat et al., 2015). It seems that fresh weight of branches can have major impacts on essential oil yield.

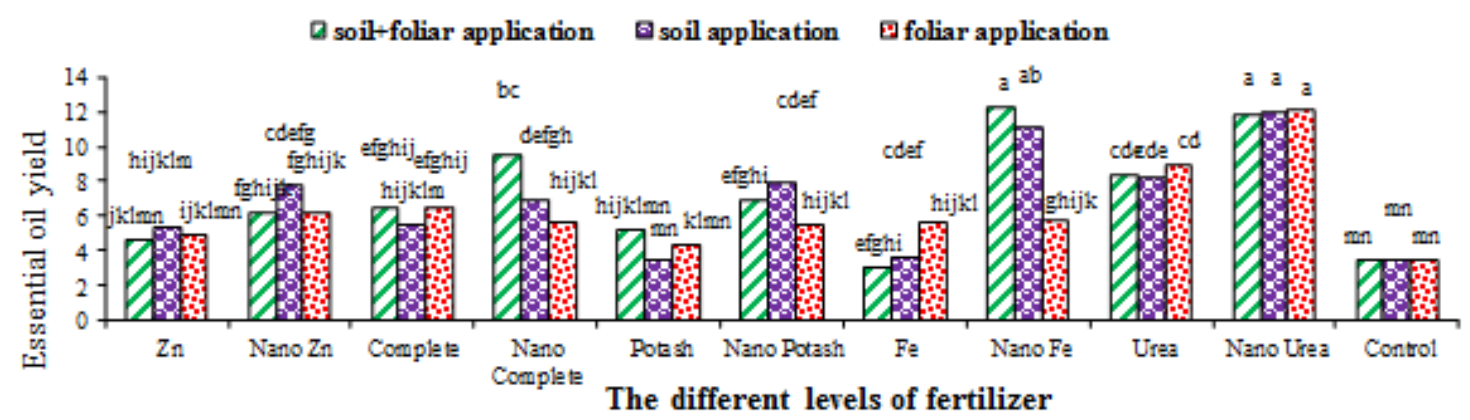

Figure 7. Interaction between type and application procedure of fertilizers on essential oil yield (\%) during 2014 year

\section{Nitrogen physiological efficiency}

Analysis of variance of nitrogen physiological efficiency showed that year, fertilizer type and application method had no significant effect on the mentioned parameters (Table 4). Physiological efficiency can be influenced by geographical condition. On the other hand, the loss of nitrogen in environment is known as reason for decreased nitrogen efficiency (Fallah and Tadayyon, 2010). The lack of difference among groups may be attributed to similar loss in all the groups. Some studies have shown inappropriate release of nitrogen regarding plant needs as reason for difference among groups (Russo et al., 2009). Increased the traits depends on ability the use of absorbed nitrogen, so that as plant produces more grain yield, physiological efficiency increases. Thus, one of efficient factors in increasing nitrogen physiological efficiency is chlorophyll production and produced dry matter. It can be stated that similar production of chlorophyll and produced dry matter can be reason for similar nitrogen physiological efficiency.

\section{Phosphorous physiological efficiency}

Analysis of variance for phosphorous physiological efficiency during 2013 and 2014 years showed that fertilizer type and application method had no significant effect on phosphorous physiological efficiency. As phosphorous efficiency increases, phosphorous can be fixed in soil (Bahl and Toor, 2002). It seems that fixation have not occurred in the current study. 


\section{Potassium physiological efficiency}

Analysis of variance for potassium physiological efficiency during 2013 year showed that fertilizer type, application method and its interaction on the mentioned parameters were not significant $(P>0.05)$. Results indicated a significant interaction between fertilizer type and application method on potassium physiological efficiency (Table 4). Analysis of variance for potassium physiological efficiency showed a significant interaction between fertilizer type and application type in 2014 year $(\mathrm{P}<0.05)$. Results showed that the most potassium physiological efficiency was observed in combined application and/or foliar application of nano iron $(0.70 \mathrm{~kg} / \mathrm{kg})$, potassium $(0.63 \mathrm{~kg} / \mathrm{kg})$ and soil application of nano-urea $(0.58 \mathrm{~kg} / \mathrm{kg})$ and nano-iron $(0.56 \mathrm{~kg} / \mathrm{kg})$. Foliar and combined application of nano-iron increased potassium physiological efficiency in comparison to soil and combined application of iron fertilizer by $91 \%$. It seems that application of potassium fertilizer increases efficiency which can be attributed to provide the nutrients for plant growth.

Table 4. Analysis of variance of physiological efficiency $(\mathrm{kh} / \mathrm{kg})$ in borage

\begin{tabular}{|c|c|c|c|c|c|c|}
\hline Sources of variation & df & \begin{tabular}{|c|} 
Nitrogen \\
physiological \\
efficiency \\
\end{tabular} & \begin{tabular}{|c|} 
Phosphorous \\
physiological \\
efficiency
\end{tabular} & \begin{tabular}{|c|} 
Potassium \\
physiological \\
efficiency \\
\end{tabular} & \begin{tabular}{|c|} 
Zinc \\
physiological \\
efficiency
\end{tabular} & \begin{tabular}{|c|} 
Iron \\
physiological \\
efficiency
\end{tabular} \\
\hline Year & 1 & $5.15^{\mathrm{ns}}$ & $3.36^{\mathrm{ns}}$ & $0.699^{\mathrm{ns}}$ & $0.962^{\mathrm{ns}}$ & $0.001^{\mathrm{ns}}$ \\
\hline Replication (year) & 4 & $19.005^{* *}$ & $25.29^{* *}$ & $1.52^{* *}$ & $1.62^{\mathrm{ns}}$ & $0.00024^{* *}$ \\
\hline Fertilizer type & 9 & $1.19^{\mathrm{ns}}$ & $11.83 \mathrm{~ns}$ & $0.207^{\mathrm{ns}}$ & $4.28^{\mathrm{ns}}$ & $0.000092^{\text {ns }}$ \\
\hline Year $\times$ fertilizer type & 9 & $3.43^{\mathrm{ns}}$ & $9.56^{\mathrm{ns}}$ & $0.079^{\mathrm{ns}}$ & $3.93^{\mathrm{ns}}$ & $0.000065^{* *}$ \\
\hline $\begin{array}{c}\text { Replication } \times \text { fertilizer } \\
\text { type (year) }\end{array}$ & 36 & $3.12^{\mathrm{ns}}$ & $9.15^{* *}$ & $0.06^{* *}$ & $6.93^{\text {ns }}$ & $0.000023^{\text {ns }}$ \\
\hline Application type & 2 & $8.41^{\mathrm{ns}}$ & $10.35^{\mathrm{ns}}$ & $0.126^{* *}$ & $8.85^{\mathrm{ns}}$ & $0.000074^{\mathrm{ns}}$ \\
\hline $\begin{array}{c}\text { Fertilizer } \\
\text { type } \times \text { application type }\end{array}$ & 18 & $2.02^{\mathrm{ns}}$ & $6.53^{\mathrm{ns}}$ & $0.143^{* *}$ & $3.82^{\mathrm{ns}}$ & $0.000073^{\text {ns }}$ \\
\hline Year×application type & 2 & $2.20^{\mathrm{ns}}$ & $3.30^{\mathrm{ns}}$ & $0.0008^{\mathrm{ns}}$ & $8.47^{\mathrm{ns}}$ & $0.000036^{\mathrm{ns}}$ \\
\hline $\begin{array}{c}\text { Year } \times \text { application } \\
\text { type } \times \text { fertilizer type }\end{array}$ & 18 & $4.59^{\mathrm{ns}}$ & $4.77^{\mathrm{ns}}$ & $0.024^{\mathrm{ns}}$ & $3.63^{\text {ns }}$ & $0.000019^{\mathrm{ns}}$ \\
\hline Error & 80 & 2.91 & 4.02 & 0.031 & 4.88 & 0.000046 \\
\hline $\mathrm{CV}(\%)$ & - & 330.39 & 163.03 & 59.87 & 2117.34 & 176.96 \\
\hline
\end{tabular}

ns: non- significant, $* *$ and $*$ significant at the $1 \%, 5 \%$ probability levels, respectively

Results also showed that foliar application of nano-zinc $(0.48 \mathrm{~kg} / \mathrm{kg})$ had the most potassium physiological efficiency but it had not significant difference with foliar application of nano-zinc $(0.27 \mathrm{~kg} / \mathrm{kg})$ and soil application of nano-zinc $(0.33 \mathrm{~kg} / \mathrm{kg})$. Foliar and combined application of complete fertilizers increased potassium physiological efficiency. Results showed that soil application of complete fertilizer and 
foliar application of nano-complete decreased potassium physiological efficiency but it was no observed significant difference between the mentioned treatments. It can be stated that potassium fertilizers had highest potassium physiological efficiency in comparison to other treatments. Results also showed that soil application of nano-iron $(3.84 \mathrm{~kg} / \mathrm{kg})$ increased potassium physiological efficiency, but the difference was not significant with soil application of nano-iron $(3.48 \mathrm{~kg} / \mathrm{kg})$. Results showed that application of nano-iron could show significant difference with iron chemical fertilizer. Results showed that the lowest potassium physiological efficiency was observed in foliar application of urea. The most potassium physiological efficiency was observed in application of urea $(2.70 \mathrm{~kg} / \mathrm{kg})$.

\section{Zinc physiological efficiency}

Analysis of variance showed that fertilizer types and their application had no significant effects on zinc physiological efficiency during 2013 year. There was significant interaction between fertilizer types and fertilizer application during 2014 year. The data for analysis of variance showed that year, fertilizer type, application method and their interactions on zinc physiological efficiency were not significant (Table 4).

\section{Iron physiological efficiency}

Analysis of variance showed that different levels of fertilizer on iron physiological efficiency was significant $(P<0.01)$. Mean comparison of iron physiological efficiency showed that highest iron physiological efficiency was observed in zinc fertilizer $(0.016$ $\mathrm{kg} / \mathrm{kg})$. The lowest iron physiological efficiency $(0.003 \mathrm{~kg} / \mathrm{kg})$ was observed in complete nano and iron which had no significant difference with other treatments. Results also indicated significant interaction between year and fertilizer type on iron physiological efficiency $(P<0.01)$. The data for mean comparison showed that highest iron physiological efficiency $(0.016 \mathrm{~kg} / \mathrm{kg})$ was observed in zinc fertilizer in first year.

\section{Conclusion}

This study was conducted to investigate the effects of chemical and nano fertilizers on crop physiological efficiency and essential oil production under foliar and soil application during 2013 and 2014 years. Our findings showed that nano-urea fertilizer had the most essential oil yield in comparison control group. Results showed that highest potassium physiological efficiency was observed in soil application and combined application of nano-iron and the most zinc physiological efficiency was observed in zinc fertilizer. It can be stated that urea and nano-urea fertilizers increase essential yield by increasing chlorophyll index, leaf area and increased fresh weight. For increasing the essential oil yield, use of nano-urea can be suggested.

Conflict of Interest. The authors report that they have no financial or personal relationships that could inappropriately influence or bias the content of the paper. 


\section{REFERENCES}

[1] Akamine, H., Hossain, A., Ishimine, Y., Yogi, K., Hokama, K., Iraha, Y., Anija, Y. (2007): Effects of application of N, P and K, alone and in combination on growth and yield and curcumin content of turmeric. - Plant Production Science 10: 151-154.

[2] Amujoyegbe, B. J., Opabode, J. T., Olayinka, A. (2007): Effect of organic and inorganic fertilizer on yield and chlorophyll content of maize (Zea mays L.) and Sorghum bicolor (L.) Moench). - African Journal of Biotechnology 6: 1869-1873.

[3] Bahl, G. S., Toor, G. S. (2002): Influence of poultry manure on phosphorus availability and the standard phosphate requirement of crop estimate from quantity-intensity relationships in different soils. - Bioresource Technology 85: 317-322.

[4] Balasubramanian, P., Palaniappan, S. P. (2001): Principles and Practices of Agronomy. Tata McGraw-Hill Publishing Co. Ltd., New Delhi, India.

[5] Baranauskieneú, R., Venskutonis, P., Visÿkelis, P., Dambrauskiene, E. (2003): Influence of Nitrogen Fertilizers on the Yield and Composition of Thyme (Thymus vulgaris). Journal of Agriculture and Food Chemistry 51: 7751-7758.

[6] Barbieri, P. A., Echeverría, E. H., Rozas, H. R. S., Andrade, F. H. (2008): Nitrogen use efficiency in maize as affected by nitrogen availability and row spacing. - Agronomy Journal 100: 1094-1100.

[7] Barrena, R., Casals, E., Colon, J., Font, X., Sanchez, A., Puntes, V. (2009): Evaluation of the ecotoxicity of model nanoparticles. - Chemosphere 75: 850-857.

[8] Biesiada, A., Kucharska, A. (2008): The effect of nitrogen fertilization on yielding and antioxidant activity of Lavender (Lavandula angustifolia Mill.). - Acta Scientiarum Polonurom Hortorum Cultus 7(2): 33-40.

[9] Briat, J.-F., Duc, C., Ravet, K., Gaymard, F. (2010): Ferritins and iron storage in plants. Biochimistry Biophysic Acta 1800: 806-814.

[10] Das, K., Dang, R., Shivananda, T. N., Şekeroğlu, N. (2007): Comparative efficiency of bio- and chemical fertilizers on nutrient contents and biomass yield in medicinal plant Stevia rebaudiana Bert. - International Journal of Natural Engineering Science 1: 35-39.

[11] Dastborhan, S., Zehtab-Salmasi, S. Nasrollahzadeh, S., Tavassoli, A. R. (2010): Effect of plant growth-promoting Rhizobacteria and nitrogen fertilizer on yield and essential oil of German chamomile (Matricaria chamimilla L.). - Journal of Agroecology 4(1): 565-573.

[12] Delbert, E. J., Ulter, R. A. (1989): Sunflower growth and nutrient uptake: Response of tillage system, hybrid maturity and weed control method. - Soil Science Journal 53: 133138.

[13] El Gendy, A. G., Taghred, A., Hegazy, B., El-Sayed, S. M. (2013): Effect of biofertilizers and/or urea on growth, yield, essential oil and chemical compositions of Cymbopogon Citratus plants. - Journal of Applied Sciences Research 9(1): 309-320.

[14] Elfeky, S. A., Mohammed, M. A., Khater, M. S., Osman, Y. A. H., Elsherbini, E. (2013): Effect of magnetite Nano-Fertilizer on Growth and yield of Ocimum basilicum L. International Journal of Indigenous Medical Plant 46: 1286-1292.

[15] Fallah, S., Tadayyon, A. (2010): Uptake and nitrogen efficiency in forage maize: effects of nitrogen and plant density. - Agrociencia 44: 549-560.

[16] Fhatuwani, N. (2008): Effects of nitrogen, phosphorus, and potassium nutrition on total polyphenol content of bush tea (Athrixia phylicoides L.) leaves in shaded nursery environment. - Hortscience 42(2): 334-8.

[17] Flowers, M., Weisz, R., Heiniger, R., Osmond, D., Crozier, C. (2004): In-season optimization and site-specific nitrogen management for soft red winter wheat. Agronomy Journal 96: 124-134.

[18] Gendy, A., Said-Al Ahl, H., Mahmoud, A., Mohame, H. (2013): Effect of nitrogen sources, bio-fertilizers and their interaction on the growth, seed yield and chemical composition of guar plants. - Life Science Journal 10(3): 389-402. 
[19] Hassani, A., Tajali, A. K., Hosseini Mazinani, S. M. (2015): Studying the Conventional chemical fertilizers and nano-fertilizer of iron, zinc and potassium on quantitative yield of the medicinal plant of peppermint (Mentha piperita L.) in Khuzestan. - International Journal of Agriculture Innovations and Research. 3: 1078-1082.

[20] Ibrahim, M. H., Jaafar, H. Z. E., Karimi, E., Ghasemzadeh, A. (2013): Impact of organic and inorganic fertilizers application on the phytochemical and antioxidant activity of Kacip Fatimah (Labisia pumila Benth). - Molecular 18: 10973-10988.

[21] Kennedy, I. R., Choudhury, M. A., Kecskes, M. L. (2004): Non-symbiotic bacterial diazotrophs in crop-farming systems: can their potential for plant growth promotion be better exploited. - Soil Biology Biochemistry 36: 1229-1244.

[22] Kottegoda, N., Munaweera, I., Madusanka, M., Karunaratne, V. (2011): A green slowrelease fertilizer composition based on urea-modified hydroxyapatite nanoparticles encapsulated wood. - Current Science 101(1): 73-78.

[23] Lee, W. L., Mahendra, S., Zodrow, K., Li, D., Tsai, Y. C., Braam, J., Alvarez, P. J. J. (2010): Developmental phytotoxicity of metal oxide nanoparticles to Arabidopsis thaliana. - Environmental Toxicology Chemistry 29: 669-675.

[24] Lee, W. M., An, Y. J., Yoon, H., Kweon, H. S. (2008): Toxicity and bioavailability of copper nanoparticles to the terrestrial plants mung bean (Phaseolusradiatus) and wheat (Triticumaestivum): plant agar test for water-insoluble nanoparticles. - Environmental Toxicology Chemistry 27: 1915-1921.

[25] Lucy, M., Reed, E., Glick, B. R. (2004): Application of free living plant growth promoting rhizobacteria. - Antonie Van Leeuwenhoek 86: 1-25.

[26] Lv, J., Zhang, S., Luo, L., Zhang, J., Yang, K., Christie, P. (2015): Accumulation, speciation and uptake pathway of $\mathrm{ZnO}$ nanoparticles in maize. - Environmental Science Nano 2: 68-77.

[27] Mhamdi, B., Aidi Wannes, W., Marzouk, B. (2007): Biochemical evaluation of borage (Borago officinalis) rosette leaves through their essential oil and fatty acid composition. Italian Journal of Biochemistry 56(2): 176-179.

[28] Moll, R. H., Kamprath, E. J., Jackson, W. A. (1982): Analysis and interpretation of factors which contribute to efficiency of nitrogen utilization. - Agronomy Journal 74: $562-564$.

[29] Najafi Vafa, Z., Sirousmehr, A. R., Ghanbari, A., Khammari, I., Falahi, N. (2015): Effects of nano-zinc and humic acid on quantitative and qualitative characteristics of savory (Satureja hortensis L.). - International Journal of Biosciences 6: 124-136.

[30] Roghayyeh, S. M., S., Mehdi, T., Rauf, S. (2010): Effects of Nano-Iron Oxide Particles on Agronomic Traits of Soybean. - Notulae Science Biology 2: 10-15.

[31] Russo, M. A., Belligno, A., Wu, J. Y., Sadro, V. (2010): Comparing mineral and organic nitrogen fertilizer impact on soil-plant-water system in a succession of three crops. Recent Research in Science and Technology 2: 14-22.

[32] Sharma, H., Kumar, A. (2011): Effect of plant growth regulators and chemical fertilizers on growth and productivity of Chlorophytum tuberosum and Pergularia daemia. - Journal of Medical Plant Research 5: 2647-2651.

[33] Siddiqui, M. H., Al-Whaibi, M. H. (2014): Role of nano-SiO2 in germination of tomato (Lycopersicum esculentum seeds Mill.). - Saudi Journal of Biological Science 21: 13-17.

[34] Zhang, T., Liao, X., Yang, R., Xu, C., Zhao, G. (2013): Different effects of iron uptake and release by phytoferritin on starch granules. - Journal of Agriculture and Food Chemistry 61: 8215-8223. 